\title{
Tracing the arc of my pedagogical partnerships: Guided by a commitment to community
}

\author{
Mary Cott, Haverford College, United States of America.
}

Contact: mcott30@gmail.com

I began my work as a student consultant in the Students as Learners and Teachers (SaLT) program for the Teaching and Learning Institute at Bryn Mawr and Haverford Colleges in the fall of my junior year. I worked with a faculty member in the computer science department at Haverford College with a focus on creating an inclusive classroom community, which my faculty partner and I described as one in which students of all genders, socioeconomic statuses, and races would be able to confidently participate in the classroom space. As the semester progressed, my role expanded from this one-on-one partnership as I was given the opportunity to attend four other courses in the same department. This wider perspective allowed me to examine each independent classroom as a singular whole working together to build a robust and meaningful computer science community.

After this rewarding pedagogical partnership with the new computer science faculty member had concluded, I was ecstatic to have the opportunity to continue my partnership journey through my senior year with an experienced faculty member in the education department. As part of this particular partnership, I was tasked with undertaking an independent study of the faculty member's recently transitioned education course, while also taking on the role of teaching assistant, during which I co-created, witnessed, and analyzed pedagogical practices that fostered and nourished community-building in online teaching and learning. My own commitment to community was informed and deepened through these partnerships, and in this reflective essay I share my experiences of these moments and what I learned from them.

\section{THE FIRST SEGMENT OF MY PARTNERSHIP ARC}

In my more "traditional" pedagogical partnership with a faculty partner, a professor of computer science, I took weekly observational notes separated into two columns: observations and questions/reflections. During weekly meetings with this faculty partner, we discussed salient moments and questions from these notes, often with a focus on gender and participation. This gender lens was activated due to both my positionality as a white woman entering a male-dominated classroom as well as the faculty member's positionality as a white woman. My single-sex education from Kindergarten through $12^{\text {th }}$ grade propelled me into a co-educational college armed with confidence to speak my mind: critiquing and analyzing this male-dominated space, despite being a challenge, came relatively easily to me. 
My faculty partner and I routinely confronted examples in which male students occupied more space in the class than their female counterparts; for example, the second time I attended her course, students were paired together for group work, and after the class reconvened for a full-class discussion, only the male students spoke. My faculty partner and I asked together, "How can we invite voices that are frequently silenced (think: gender, race, etc.) in computer science and what kind of scaffolding can we use to support each voice in the classroom?" Student voices prove vital in building classroom communities. Yet, it became clear to me during this work that the (in)ability of a student to use their voice is inextricably linked to inequitable educational structures at work in classroom spaces, which are informed by my own, students', and the faculty members' identities. This partnership work ultimately effected change by sparking departmental discussions on racism and sexism within computer science classrooms and created space for students whose voices were typically excluded from this white- and male-dominated sphere to be heard.

My faculty partner encouraged the expansion of my role as her student consultant by putting me in touch with other faculty (three men and one woman) in her department where I attended four more computer science courses throughout the semester in which I observed similar participation disparities according to gender. I was thrilled to be able to impact not just her classroom, but computer science classrooms as a whole at Haverford. I reported back to my primary faculty partner, with whom I had spent time building trust and respect, about all of my observations, having taken notes in these other classrooms in the same format. She then brought my feedback to her colleagues.

This partnership originally focused on making only one computer science course scaffolded with support for students of all identities to participate-a partnership built through dialogue and collaboration in order to combat one aspect of the systemic inequalities at play in the classroom. However, the inequities at play were and remain daunting, and I was worried about how my partnership work could combat a systemic issue. I was therefore encouraged when my partnership expanded to have a wider impact by analyzing four other computer science classrooms in an effort to make the department as a whole more accessible to students. My partnership work sparked departmental conversations amongst the computer science faculty concerning how gender, along with many other dimensions of identity such as race and socioeconomic status, influences participation in their classrooms. This work felt meaningful. Indeed, as the class continued, I noticed changes in how my primary faculty member would ask students to participate. For example, she would notice when only white, male students spoke up and would encourage, without pressuring, students of other identities to speak by urging students who had not yet had the opportunity to speak that day to participate. I felt heartened that my partnership work, which targeted a vast, systemic issue, had created changes not only in the individual classes I observed, but had also sparked a departmental focus on how to develop an inclusive community, which made room for students of various identities to contribute to the space. In fact, a focus on community became a common thread in my subsequent partnership work.

\section{THE SECOND SEGMENT OF MY PARTNERSHIP ARC}

When the COVID-19 crisis hit, I knew working in partnership with a faculty member would prove to be even more essential. Given that teaching and learning would operate differently that semester due to the pandemic, the sense of community would be 
significantly disrupted for students and faculty members alike during the era of social distancing and online teaching and learning. Having been abruptly sent home from my study abroad program the spring of my junior year and jumping into remote learning at Haverford for the first time during the fall of my senior year, I missed my college community. I was committed to working in partnership to target this loss of connection due to the switch to remote learning. Thus, I was fortunate to continue in my partnership work, which maintained momentum amidst the myriad of issues created by the pandemic, and to have the opportunity to work with a faculty member teaching an education course with a focus on community.

Due to the switch to remote learning and the critically necessary focus on building, maintaining, and sustaining community in the classroom, I met with my new faculty partner and discussed the format of my partnership, which included a focus on community. As such, instead of sharing my weekly observational notes with my faculty partner, I compiled my notes into a document called "Effective Pedagogical Approaches For Community-Building in Online Spaces" that would be shared with all faculty (from departments ranging from French to Computer Science to Gender and Sexuality Studies) involved in their own partnership work through the Teaching and Learning Institute. I met with my faculty partner throughout the semester online to talk about what I was noticing in her virtual classroom, my responsibilities in the course as a teaching assistant (such as moderating the discussion board), and to discuss connections between our lived experience in the online classroom and what scholars were writing about community-building in online spaces. At the end of the semester, I polished my list of suggestions, citing what my faculty partner and I noticed went well in her education course. The Director of the Teaching and Learning Institute then shared my document, which was separated into five sections, on the Moodle page that all those in pedagogical partnerships have access to at Haverford. The sections in my document included: beginning of class/check-ins, breakout rooms, acknowledging the online space, student voices, and student care. These sections emerged organically when organizing my observational notes. The routinized beginning of class as well as time spent in breakout rooms spoke directly to how community was being constructed in this class. The acknowledgment of the online space by the faculty member proved to be a salient moment in which online learning was seen as a benefit rather than a drawback of the course. Lastly, student voices and student care were central in the construction of this student-oriented community-a classroom community cannot be the responsibility of the faculty member on their own, but students themselves must engage with their peers through breakout rooms, full class discussions, and the in-built chat feature on Zoom. The document also contained a suggested reading list for further exploration in order to root this study of community in scholarly research.

Faculty teaching during the pandemic were confronted with teaching in a way that is foreign to them. In response to this rupture between faculty members' educational autobiographies and the current climate of remote learning, I set out to write "Effective Pedagogical Approaches for Community-Building in Online Spaces." I went into this work having had experiences being a student in my faculty partner's previous courses in which I built close relationships with the faculty member and my peers due to her clearly intentional focus on community. Balancing this work with my other schoolwork went smoothly because focusing on community-building in online learning was not unique to the class that my faculty partner was teaching, but was a part of each and every class I found myself in. I created this document to validate my faculty partner's centralization of 
community-building in the online sphere and, by sharing it with other student consultants and faculty in the SaLT program, to encourage others to center community in the classroom.

In addition to supporting faculty, this resource attempted to support students as well, given that they are also charting the largely unknown terrain of online learning. Studying community during this time of trauma was vital in order to understand how to best support student success. It is worth noting that there are varying levels of trauma, which would indicate that community is lost by varying degrees based on a person's identity and situation. My own experience as a student living off campus in my college town with one roommate during the COVID-19 pandemic showcased that when I felt a deeper sense of belonging with my peers and professors in various Zoom classes, I was more easily able to engage, participate, and pay closer attention. Ultimately, I was more successful in courses in which I felt part of a community. However, the goal of community-building should not be solely for the purpose of student success in terms of grades and student performance. Building relationships for the purpose of improving student success would be insincere relationships; rather, we must cultivate learning environments that build sincere connections and foster a sense of belonging. For a genuine community to be built, students and faculty alike must create meaningful relationships that transcend content.

Through my observations of building, sustaining, and maintaining community in an online environment, using an education course as an exemplar, I attempted to translate pedagogical techniques I witnessed in the classroom and discussed in regular meetings with my faculty partner into templates for other faculty members to engage with in order to support students in their classrooms. These techniques seemed successful because they enabled me, as both a teaching assistant and community member involved in the classroom, to feel a sense of belonging when attending this virtual Zoom classroom. Some examples of community-building tactics include centering the use of student names in the classroom, which I explained in the resource is effective because it "helps students to feel part of a community. They know they are seen and heard by their professor and their peers. They are seen as an integral part of the online learning space." I felt confident in my descriptions of how the use of student names in the classroom impacts students given that, from my own experiences when my faculty partner used my name in the classroom, I felt acknowledged and able to bring my full self to the learning space. Establishing a routine is another critical way to build community in an online classroom because, as I write in the resource, it "gives students a sense of normalcy and community" as well as "explicitly alleviat[ing] anxiety in an attempt to create a class norm." Lastly, focusing on the benefits of online learning, such as collaborative notetaking over Google Docs and live polling over Zoom, instead of attempting to replicate what would be done if the course were held in person "takes advantage of online space, instead of seeing that as a barrier," as I explained in the document. I gathered these examples as well as articulated why each of them were effective in a limited, biased perspective: my experience. As a student, I see the classroom through a unique set of eyes that I hope can be illuminating for professors; however, one must recognize that it is not a universal student experience, but, instead, just mine. In this document, I hoped to illustrate to faculty how they are already naturally creating and maintaining community in online spaces, as well as to provide them with new ideas to nourish their communities through a perspective they would not otherwise have access to: the eyes of a student in their classroom.

All of these tactics mentioned above suggest how a faculty member can build and maintain an online classroom; however, it is worth noting that faculty members are only 
able to contribute so much to a community. The burden does not fall entirely on the faculty: students are key players as well. As Eileen McElrath and Kate McDowell (2008) explain: "while the instructor can facilitate the building of community, some researchers assert that, ultimately, students must build their own community" (p. 119). Providing the scaffolding for students to do so, however, is a crucial component of teaching. Without such scaffolding, a community cannot be successfully built. The faculty member's encouragement of students to build their own community sets the stage for that to take place. In the course I observed, when the faculty member stepped away from the Zoom for a moment, two students spoke: "It's nice to see you all again" and "I've missed class and it's nice to see all your faces again." Despite the faculty member's absence during this moment, it was because of her that this student interaction took place: her consistent check-ins with students on their well-being as well as her regular urging that students introduce themselves to each other in breakout rooms centered the human in the classroom. My faculty partner made clear that she cared about the students in the classroom; students, with such support, were then able to see, engage with, and care for their peers. As I wrote in "Effective Pedagogical Approaches for Community-Building in Online Spaces," this moment situates students as "critical players in creating a classroom community. The role the faculty member plays in creating the scaffolding for this building is critical; however, it is up to the students to contribute to the community." This moment felt like a relief: I could not help but smile as I heard these students building a genuine, authentic community entirely on their own without the faculty member's presence. It indicated that despite a semester in which students were isolated and a lack of community seemed to pervade, students were able to create meaningful relationships with one another. I was honored to be able to learn from and with my faculty partner and be part of this classroom community.

\section{CONCLUSION}

Building community is central in both in-person and online teaching and learning. As described by Jesse Stommel (2018) in "...the course (Pedagogy section), "community and dialogue shouldn't be an accident or by-product of a course. They should be the course." In my more "traditional" pedagogical partnership, I was set on creating space for students typically excluded in the field of computer science, which caused the building of an inclusive and meaningful community to emerge as a theme. As I entered my second partnership in an education course, my focus was already set on community-building, which was ignited both by my experience with my first partnership and with the move to online learning. This study of community through these two experiences will inform my practice not only as a student but also a teacher. In the next stage of my arc, I will graduate and step into the role of an educator knowing that authentic community-building is integral to successful learning environments with concrete examples of effective practices. I commit to do this work as an educator: I commit to building, maintaining, and nourishing each community of which I am a part.

\section{NOTE ON CONTRIBUTOR}

Mary Cott graduated from Haverford College in the spring of 2021, where she majored in Comparative Literature and minored in French and Francophone Studies and Educational Studies. She began working as an Assistant Teacher at The Windward School in New York City during the fall of 2021. 


\section{REFERENCES}

McElrath, E., \& McDowell, K. (2008). Pedagogical strategies for building community in graduate level distance education courses. MERLOT Journal of Online Learning and Teaching, 4(1), 117-127. https://www.semanticscholar.org/paper/PedagogicalStrategies-for-Building-Community-in-McelrathMcDowell/d985dd3de25b9a1564e1d39619ece528c05cc391?p2df

Stommel, J. (2018). Online learning: A manifesto. In S. M. Morris \& J. Stommel (Eds.), An urgency of teachers: The work of critical digital pedagogy. Hybrid Pedagogy Inc. https://criticaldigitalpedagogy.pressbooks.com/chapter/online-learning-amanifesto/ 